\title{
Susceptibility of Asian citrus psyllid, Diaphorina citri (Hemiptera: Liviidae), to the insecticide afidopyropen: a new and potent modulator of insect transient receptor potential channels
}

\author{
Xue Dong Chen ${ }^{1}$ (1) $\cdot$ Muhammad Ashfaq ${ }^{1,2} \cdot$ Lukasz L. Stelinski $^{1}$
}

Received: 23 March 2018 / Accepted: 27 June 2018 / Published online: 18 July 2018

(c) The Author(s) 2018

\begin{abstract}
A relatively new insecticide chemistry for controlling sucking insects, afidopyropen, was investigated for toxicity against Asian citrus psyllid, Diaphorina citri Kuwayama (Hemiptera: Liviidae). We evaluated the mortality of D. citri eggs, nymphs, and adults treated with afidopyropen using both laboratory-reared and field populations. We also quantified the effects of sublethal doses of afidopyropen on $D$. citri feeding, host choice selection, and fecundity. For laboratory susceptible adults, the contact $\mathrm{LC}_{50}$, topical application $\mathrm{LD}_{50}$, and leaf dip $\mathrm{LC}_{50}$ were $2.13,2.00$, and $3.08 \mathrm{ng} / \mu \mathrm{L}$, respectively. For adults collected from a commercially managed citrus grove in Florida, the contact $\mathrm{LC}_{50}$, topical application $\mathrm{LD}_{50}$, and leaf dip $\mathrm{LC}_{50}$ were $1.37,1.92$, and $4.89 \mathrm{ng} / \mu \mathrm{L}$, respectively. Egg hatch was significantly reduced following exposure to afidopyropen at $100 \mathrm{ng} / \mu \mathrm{L}$. Furthermore, afidopyropen reduced $D$. citri nymph survival and adult emergence at concentrations ranging between 0.01 and $100 \mathrm{ng} / \mu \mathrm{L}$. Diaphorina citri adult feeding decreased on citrus leaves treated with afidopyropen in a concentration-dependent manner as measured indirectly by honeydew excretion, and appeared almost completely inhibited after treatment with 10 and $100 \mathrm{ng} / \mu \mathrm{L}$ solutions of afidopyropen. In choice tests, significantly fewer $D$. citri adults settled on afidopyropen-treated plants than on control plants at 24,48 , and $72 \mathrm{~h}$ after release, with no differences in settling between males and females. Afidopyropen reduced the fecundity of $D$. citri in a concentration-dependent manner. Collectively, the results suggest that afidopyropen could contribute to the integrated management of $D$. citri and may therefore be useful in rotational programs to improve resistance management.
\end{abstract}

Keywords Huanglongbing (HLB) $\cdot$ Toxicity bioassay $\cdot$ Sublethal doses $\cdot$ Insecticide resistance $\cdot$ Antifeedant effect

\section{Introduction}

The Asian citrus psyllid, Diaphorina citri Kuwayama (Hemiptera: Liviidae), is a serious pest across Asia, USA, and Brazil (FFTC 2009, 2012; Kiritani and Su 1999; Narouei-Khandan et al. 2015; Rogers 2008; Shinohara et al. 2006; Stansly and Rogers 2006; Tomimura et al. 2014). Diaphorina citri is a severe economic pest for at least three reasons. First, it has a relatively wide range of

Lukasz L. Stelinski

stelinski@ufl.edu

1 Entomology and Nematology Department, IFAS, Citrus Research and Education Center, University of Florida, Lake Alfred, FL 33850-2299, USA

2 Department of Entomology, University of Agriculture Faisalabad, University Main Road, Faisalabad 38000, Pakistan hosts, encompassing at least ten genera in addition to Citrus (Grafton-Cardwell et al. 2013). Second, D. citri can develop and reproduce rapidly, allowing populations to build quickly (Liu and Tsai 2000). A female can oviposit nearly 800 eggs per lifetime on average onto young leaf tissue, particularly newly expanded flush (Hall and Albrigo 2007; Liu and Tsai 2000). Third, D. citri transmits Candidatus Liberibacter asiaticus, which is associated with huanglongbing (HLB) disease in citrus (Huang et al. 1984; Tiwari et al. 2011). HLB has a major economic impact and occurs across a wide geographic range (Halbert 2005; Halbert and Manjunath 2004; Langdon and Rogers 2017). The management of HLB is currently accomplished by vector suppression. Therefore, $D$. citri is managed with multiple applications of insecticides, but there are a limited number of modes of action available per growing season (Baldessari et al. 2010; GraftonCardwell et al. 2013; Qureshi et al. 2014; Yasui et al. 1985). 
Additional chemistries are needed in current management rotations for $D$. citri to delay the development of resistance; these chemistries should also be effective against a broader range of pests affecting citrus (Rogers 2008). Afidopyropen is a new potent and specific modulator of insect transient receptor potential vanilloid (TRPV) cation channels, exhibiting unique binding (Kandasamy et al. 2017; Nilius and Owsianik 2011). It is derived from natural products (Jeschke 2017; Leichter et al. 2013). The insecticidal activity of chordotonal organ TRPV channel modulators is likely related to species selectivity at the target level and the importance of chordotonal organs for insect survival. Their mode of action involves stimulating heterologously expressed transient receptor potential channels that act by targeting nanchung (NAN) and inactive (INA) proteins (Kandasamy et al. 2017). Afidopyropen is a semi-synthetic analog of pyropropen, and was developed to target sap-feeding insects such as the pea aphid Acyrthosiphon pisum Harris (Hemiptera: Aphididae) by causing mortality through starvation and desiccation (Gerwick and Sparks 2014; Leichter et al. 2013). In contrast, afidopyropen is practically nontoxic to other species_-including German cockroach Blatella germanica (Linnaeus) (Blattodea: Blattellidae), yellow fever mosquito Aedes aegypti (Linnaeus) (Diptera: Culicidae), Colorado potato beetle Leptinotarsa decemlineata (Say) (Coleoptera: Chrysomelidae), red flour beetle Tribolium castaneum (Herbst) (Coleoptera: Tenebrionidae), house fly Musca domestica (Linnaeus) (Diptera: Muscidae), and fireflies Photuris spp. (Coleoptera: Lampyridae)—despite the presence of NAN and IAV transcripts (Leichter et al. 2013).

The effects of afidopyropen on $D$. citri have not yet been reported. We present an investigation evaluating the general toxicity of afidopyropen against $D$. citri using both a laboratory population with known susceptibility to multiple insecticide classes as well as insects collected from a field population treated with insecticides according to grower norms in Florida. Specifically, we quantified the acute and chronic toxicity of afidopyropen towards $D$. citri as well as its sublethal effects on D. citri development, feeding, and host settling behaviors.

\section{Materials and methods}

\section{Insect culture and chemical}

D. citri is continuously reared at the Citrus Research and Education Center (CREC), University of Florida (Lake Alfred, FL, USA). The D. citri culture used in this work was established in 2000 from field-collected insects in Polk County, Florida (N: $\left.28^{\circ} 0^{\prime} ; \mathrm{W}: 81^{\circ} 9^{\prime}\right)$ prior to the discovery of HLB in the state. The culture was maintained on sweet orange (Citrus sinensis (L.) Osbeck) in a greenhouse at $27-28{ }^{\circ} \mathrm{C}$ with $60-65 \%$ relative humidity and a $14: 10 \mathrm{~h}$ (L:D) photoperiod, with no exposure to insecticides. The field population of $D$. citri adults used for evaluation was obtained from commercial citrus groves in central Florida (N:28 $\left.07^{\prime} ; \mathrm{W}: 81^{\circ} 42^{\prime}\right)$. Collected $D$. citri adults were transferred to the laboratory in a cooler and released onto citrus plants in Plexiglas cages $(40 \times 40 \times 40 \mathrm{~cm})$ until they were used in bioassays. Insecticide bioassays with $D$. citri were conducted with a stock solution of afidopyropen $(100 \mathrm{~g} / \mathrm{L})$ provided by BASF Agriculture Products Group (Research Triangle Park, NC, USA).

\section{Toxicity bioassays}

An adult bottle bioassay method described previously (Chen and Stelinski 2017; Kanga et al. 2016; Snodgrass 1996) was used to evaluate direct toxicity. A leaf dip bioassay as described in Boina et al. (2009), Chen et al. (2017), and Prabhaker and Toscano (2007) was also used to evaluate the activity of afidopyropen against $D$. citri adults. Finally, an additional comparison was made with a topical application technique described in Chen et al. (2017). All bioassays included 7-9 concentrations of afidopyropen that caused between 10 and $90 \%$ mortality in preliminary assays. Afidopyropen was diluted to various concentrations in distilled water or acetone and stock solutions were prepared on the day of testing. All bioassays were conducted at $25 \pm 2{ }^{\circ} \mathrm{C}$ and $50 \pm 5 \% \mathrm{RH}$ with a 14:10 h (L:D) photoperiod in a growth chamber for 24 or $48 \mathrm{~h}$, after which mortality was assessed.

\section{Settling and host choice tests}

The objective of this experiment was to determine whether afidopyropen affects settling and host choice by $D$. citri adults under laboratory conditions. Afidopyropen was tested at a sublethal dose of $0.22(\mathrm{ng} / \mu \mathrm{L})$. Potted citrus plants-'Swingle' citrumelo (Citrus paradisi Macfadyen $\times$ Poncirus trifoliata (L.) Raf), 20-30 cm in height-were sprayed with either an aqueous solution of afidopyropen or tap water using a handheld atomizer (The Bottle Crew, West Bloomfield, MI, USA) until runoff. Plants were allowed to air dry for $1 \mathrm{~h}$ and were then transferred to mesh cages $(40 \times 40 \times 60 \mathrm{~cm})$. Each cage contained treated and control plants placed in opposite corners separated by $20 \mathrm{~cm}$. One hundred fifty $D$. citri adults of the same gender but of mixed age were released into each cage. The number of adults present on each plant was recorded 24,48 , and $72 \mathrm{~h}$ after release. Four cages were established and the entire experiment was repeated three times on different dates. 


\section{Antifeedant effect of afidopyropen as measured by honeydew excretion}

The objective of this experiment was to determine whether afidopyropen affected feeding of $D$. citri adults, as indirectly quantified by honeydew excretion. $D$. citri adults were exposed to leaves treated by the leaf dip method with 0.01 , $0.1,1,10$, or $100 \mathrm{ng} / \mu \mathrm{L}$ concentrations of afidopyropen. Five $D$. citri adults of mixed age and sex were released into each dish, and the dishes were sealed with lids lined with 35-mm Whatman filter paper (Whatman International Ltd, Kent, UK). Petri dishes were placed upside down to collect honeydew droplets on the filter paper. Dishes were maintained at $25 \pm 2{ }^{\circ} \mathrm{C}, 50 \pm 5 \% \mathrm{RH}$, and a $14: 10 \mathrm{~h}$ (L:D) photoperiod for $48 \mathrm{~h}$. Adult mortality in this experiment was very low (5\% at the highest concentration), so data from both healthy and dead/dying D. citri were included in the analysis. Collected filter paper discs were subjected to a ninhydrin (Sigma-Aldrich, St. Louis, MO, USA) test to facilitate the counting of honeydew droplets (Chen et al. 2017; Nauen and Elbert 1997). Honeydew droplets were counted $48 \mathrm{~h}$ after transfer to growth chambers. Each concentration was replicated four times and the entire experiment was repeated three times on different dates.

\section{Effect of afidopyropen on $D$. citri egg mortality following direct spray application}

Four potted 'Swingle' seedings (6-8 months old) with a new leaf flush were placed into Plexiglas cages $(40 \times 40 \times 40 \mathrm{~cm})$ with fine mesh sleeves for easy access. Plants were exposed to 300-400 adult D. citri of mixed gender for $48 \mathrm{~h}$ for mating and oviposition at $25 \pm 2{ }^{\circ} \mathrm{C}$ and $50 \pm 5 \% \mathrm{RH}$, and under a 14: $10 \mathrm{~h}$ (L:D) photoperiod. Thereafter, adults were removed from the cages and the number of eggs per flush was recorded using a stereomicroscope. Plants were sprayed with one of five concentrations $(0.01,0.1,1,10$, and $100 \mathrm{ng} /$ $\mu \mathrm{L}$ ) of afidopyropen dissolved in water until runoff using a handheld atomizer (The Bottle Crew, West Bloomfield, MI, USA). Water alone served as the control. Each treatment was replicated four times. Five days after treatment, eggs were examined under a stereomicroscope, and the number of eggs that hatched per plant was recorded. The percentage egg hatch was calculated using the total number of eggs recorded before treatment and the number of hatched eggs recorded five days post-treatment.

\section{Effect of afidopyropen on $D$. citri nymphs and adult emergence}

A stem dip bioassay was used to evaluate the effects of afidopyropen on $D$. citri nymph mortality and adult emergence for both field and laboratory populations. Nymphs were treated as fourth to fifth instars and allowed to develop into adults. The bioassay method was a slight modification of the leaf dip method where approximately $3 \mathrm{~cm}$ of the citrus stem containing ca. 1750 (laboratory) or 1400 (field population) fourth- to fifth-instar nymphs were dipped into aqueous solutions of afidopyropen (0.01, $0.1,1,10$, and $100 \mathrm{ng} / \mu \mathrm{L}$ ) prepared freshly on the day of testing or into tap water alone. After treatment, the treated nymphs were returned to untreated leaf discs as described in Chen et al. (2017). The number of dead nymphs was recorded at $72 \mathrm{~h}$ and adult emergence was also recorded at six days after exposure. Each treatment was replicated 3-6 times. The experiment was repeated twice for the field population and three times for the laboratory population. Each experiment was evaluated separately with a corresponding negative control treatment. The treated stems with nymphs were maintained at $25 \pm 2{ }^{\circ} \mathrm{C}$ and at $50 \pm 5 \%$ RH in an insectary under a 14:10 h (L:D) photoperiod.

\section{Effect of afidopyropen on $D$. citri growth and development}

Potted 'Swingle' plants (2-3 months old) with a new leaf flush were used for this experiment. The experiment was arranged in a randomized complete block design comprising six treatments with four replicates. The entire experiment was repeated twice. The six treatments consisted of five concentrations $(0.01,0.1,1,10$, and $100 \mathrm{ng} / \mu \mathrm{L})$ of afidopyropen dissolved in water and a water control. Treatments were applied with a handheld atomizer delivering a volume of $10 \mathrm{~mL}$ per plant until runoff. Plants were allowed to air dry and then exposed to five male and five female virgin $D$. citri adults for mating and oviposition. Each plant was covered with ventilated mesh and maintained at $25 \pm 2{ }^{\circ} \mathrm{C}$ and $50 \pm 5 \% \mathrm{RH}$ with a $14: 10 \mathrm{~h}$ (L:D) photoperiod for five days. Thereafter, adults were removed from each plant and the number of eggs per plant was recorded under a stereomicroscope. After five days, the number of eggs that hatched per plant was recorded by counting the number of first-instar nymphs per plant. Plants were observed every five days until the completion of adult emergence. The population growth rate (PGR) was calculated using the equation $\mathrm{PGR}=\ln \left(N_{\mathrm{f}} / N_{0}\right) / \Delta T$, where $N_{\mathrm{f}}$ is the final number of psyllids, $N_{0}$ is the initial number of psyllids, and $\Delta T$ is the total number of days for the experiment. Solving for PGR results in a rate of population growth similar to that obtained by the intrinsic rate of increase $\left(r_{\mathrm{m}}\right)$ (Chen et al. 2010, 2017; Chen and Stark 2010; Stark et al. 1997). Positive values of PGR indicate an increase, $P G R=0$ indicates a stable population, and negative PGR values indicate a population decline. 
Table 1 Toxicity of afidopyropen against the laboratory susceptible Diaphorina citri population

\begin{tabular}{|c|c|c|c|c|}
\hline Bioassay type & $N$ & Slope $( \pm$ SE) & Time (h) & $\begin{array}{l}\mathrm{LC}_{50}\left(\mathrm{LD}_{50}\right)(\mathrm{ng} / \\
\mu \mathrm{L})\end{array}$ \\
\hline Contact bioassay & 1057 & $0.68 \pm 0.18$ & 24 & $2.13(1.14-178.3)$ \\
\hline $\begin{array}{l}\text { Leaf dip bioas- } \\
\text { say }\end{array}$ & 913 & $0.44 \pm 0.05$ & 48 & $3.08(0.89-16.02)$ \\
\hline Topical bioassay & 257 & $0.62 \pm 0.14$ & 24 & $2.00(0.13-61.71)$ \\
\hline
\end{tabular}

Table 2 Toxicity of afidopyropen against the Diaphorina citri population collected from citrus managed with insecticides

\begin{tabular}{lllll}
\hline Bioassay type & $N$ & Slope $( \pm \mathrm{SE})$ & Time $(\mathrm{h})$ & $\begin{array}{l}\mathrm{LC}_{50}\left(\mathrm{LD}_{50}\right)(\mathrm{ng} / \\
\mu \mathrm{L})\end{array}$ \\
\hline Contact bioassay & 701 & $0.44 \pm 0.04$ & 24 & $1.37(0.76-2.58)$ \\
Leaf dip bioassay & 370 & $0.43 \pm 0.11$ & 48 & $4.89(0.22-612)$ \\
Topical bioassay & 645 & $0.43 \pm 0.07$ & 24 & $1.92(0.41-15.32)$ \\
\hline
\end{tabular}

\section{Statistical analyses}

All data were analyzed using SAS statistical software (SAS 2002-2012). Probit regression analysis was conducted to calculate $\mathrm{LC}_{50}\left(\mathrm{LD}_{50}\right)$ values and their corresponding 95\% confidence intervals (CIs) for D. citri. Data were subjected to separate one-way analyses of variance (ANOVA) and Fisher's protected least significant difference (LSD) tests (PROC GLM). Significant differences between treatment means were identified by Fisher's LSD test at $\alpha=0.05$. Similarly, significant differences between the mean percentages of egg hatch were identified by one-way ANOVA followed by the LSD test at $\alpha=0.05$. The percentage egg hatch across treatments was tested to ensure that the assumptions of homogeneity of variance and normality were met before the data were analyzed. For host choice tests, two by four contingency tables were used to analyze the data, followed by pairwise comparisons using Fisher's exact test $(\alpha=0.05)$ and the Bonferroni test $(p<0.001)$.

\section{Results}

\section{Toxicity of afidopyropen to $D$. citri adults}

The $\mathrm{LC}_{50}$ value for afidopyropen ranged between 2.00 and $3.08 \mathrm{ng} / \mu \mathrm{L}$ for the laboratory population (Table 1) and $1.37-4.89 \mathrm{ng} / \mu \mathrm{L}$ for the field population (Table 2), depending on the assay method used. There was significant mortality of $D$. citri due to treatment exposure as compared with the negative control in each case.

\section{Host settling choice tests}

Significantly fewer $D$. citri adults had alighted on afidopyropen-treated plants than on control plants at $24 \mathrm{~h}$ $\left(d f=9 ; x^{2}=1671.00 ; p<0.001\right), 48 \mathrm{~h}\left(d f=9 ; x^{2}=1521.00\right.$; $p<0.001)$, and $72 \mathrm{~h}\left(d f=9 ; x^{2}=1515.00 ; p<0.001\right)$ after release during both experiments (Table 3 ). There was no significant difference between the responses of males and females.
Table 3 Settling preferences of Diaphorina citri on untreated leaves and on leaves treated with a sublethal dose of afidopyropen

\begin{tabular}{|c|c|c|c|c|c|c|c|}
\hline \multirow{2}{*}{$\begin{array}{l}\text { Observation } \\
\text { time (h) }\end{array}$} & \multirow[t]{2}{*}{ Sex } & \multirow[t]{2}{*}{ Experiment } & \multirow[t]{2}{*}{$N$} & \multicolumn{4}{|c|}{ Number of adults } \\
\hline & & & & Control plants ${ }^{\mathrm{a}}$ & Treated plants & $\begin{array}{l}\text { Cage walls } \\
\text { and pot soil }\end{array}$ & Dead \\
\hline \multirow[t]{4}{*}{24} & \multirow[t]{2}{*}{ Male } & 1 & 150 & $114 \mathrm{a}$ & $30 \mathrm{~b}$ & 2 & 4 \\
\hline & & 2 & 150 & $100 \mathrm{a}$ & $40 \mathrm{~b}$ & 6 & 4 \\
\hline & \multirow[t]{2}{*}{ Female } & 1 & 150 & $116 \mathrm{a}$ & $24 b$ & 7 & 3 \\
\hline & & 2 & 150 & $123 \mathrm{a}$ & $25 b$ & 2 & 0 \\
\hline \multirow[t]{4}{*}{48} & \multirow[t]{2}{*}{ Male } & 1 & 150 & $106 \mathrm{a}$ & $34 \mathrm{~b}$ & 2 & 8 \\
\hline & & 2 & 150 & $84 a$ & $40 \mathrm{~b}$ & 7 & 19 \\
\hline & \multirow[t]{2}{*}{ Female } & 1 & 150 & $117 \mathrm{a}$ & $17 b$ & 12 & 4 \\
\hline & & 2 & 150 & $117 \mathrm{a}$ & $30 \mathrm{~b}$ & 3 & 0 \\
\hline \multirow[t]{4}{*}{72} & \multirow[t]{2}{*}{ Male } & 1 & 150 & $118 \mathrm{a}$ & $22 b$ & 0 & 10 \\
\hline & & 2 & 150 & $92 \mathrm{a}$ & $29 b$ & 4 & 25 \\
\hline & \multirow[t]{2}{*}{ Female } & 1 & 150 & $110 \mathrm{a}$ & $18 \mathrm{~b}$ & 18 & 4 \\
\hline & & 2 & 150 & $124 \mathrm{a}$ & $21 b$ & 3 & 2 \\
\hline
\end{tabular}

${ }^{a}$ Totals followed by the same letter in each row are not significantly different according to a contingency table test $(p>0.05)$ 


\section{Effect of afidopyropen on D. citri growth and development}

The number of eggs $(d f=5 ; F=8.01 ; p<0.004)$ laid per plant was significantly different for $D$. citri exposed to some concentrations of afidopyropen as compared with the control (Table 4). There were no significant differences between the $D$. citri treated with 0.01 or $0.1 \mathrm{ng} / \mu \mathrm{L}$ and the control. Significantly fewer eggs were laid on plants treated with 1 , 10 , or $100 \mathrm{ng} / \mu \mathrm{L}$ as compared with the control. There were no significant differences among treatments in the egg hatch rate $(d f=5 ; F=0.46 ; p=0.80)$ (Table 4$)$. There were no significant differences in population growth rate (PGR) between treatments and the control, except for the D. citri treated with 1,10 , or $100 \mathrm{ng} / \mu \mathrm{L}$; for those treatments, the mortality rates did not permit the calculation of PGRs (Table 4).

\section{Effect of afidopyropen on $D$. citri nymphs and adult emergence}

The mortality of fourth- to fifth-instar nymphs increased with increasing concentration of afidopyropen, and was greatest following treatment with the two highest concentrations tested for both laboratory $(d f=5 ; F=13.31$; $p=0.0002)$ and field $(d f=5 ; F=6.96 ; p=0.0029)$ populations (Fig. 1a, b). Treatment of fourth- to fifth-instar nymphs significantly reduced adult emergence for both laboratory $(d f=5 ; F=7.08 ; p=0.0027)$ and field $(d f=5$; $F=12.28 ; p=0.0042)$ populations at the two highest concentrations of afidopyropen tested (Fig. 1c, d).

Table 4 Effect of afidopyropen on the development of Diaphorina citri

\begin{tabular}{|c|c|c|c|c|c|}
\hline $\begin{array}{l}\text { Insecticide concentra- } \\
\text { tion }(\mathrm{ng} / \mu \mathrm{L})\end{array}$ & $\begin{array}{l}P(\text { parental }) \\
\mathrm{M} \times \mathrm{F}\end{array}$ & $\begin{array}{l}\text { No. of eggs per plant } \\
( \pm \text { SE })\end{array}$ & $\begin{array}{l}\text { Hatch rate }(\%) \\
( \pm \mathrm{SE})\end{array}$ & $\begin{array}{l}F_{1} \text { (first filial generation) } \\
\text { Adult }( \pm \text { SE) }\end{array}$ & PGR $( \pm$ SE $)$ \\
\hline Control & $5 \times 5$ & $26.50 \pm 5.51 \mathrm{a}$ & $40.97 \pm 2.82 \mathrm{a}$ & $3.50 \pm 0.29 \mathrm{a}$ & $0.53 \pm 0.30 \mathrm{a}$ \\
\hline 0.01 & $5 \times 5$ & $19.75 \pm 5.80 \mathrm{ab}$ & $39.34 \pm 4.84 a$ & $2.25 \pm 0.03 \mathrm{ab}$ & $0.71 \pm 0.04 \mathrm{a}$ \\
\hline 0.1 & $5 \times 5$ & $13.50 \pm 1.50 \mathrm{abc}$ & $43.41 \pm 7.75 \mathrm{a}$ & $2.25 \pm 0.63 \mathrm{ab}$ & $0.10 \pm 0.57 \mathrm{a}$ \\
\hline 1 & $5 \times 5$ & $6.50 \pm 2.90 \mathrm{bc}$ & $33.33 \pm 12.72 \mathrm{a}$ & $1.00 \pm 0.58 b$ & - \\
\hline 10 & $5 \times 5$ & $2.50 \pm 1.30 \mathrm{c}$ & $30.00 \pm 14.01 \mathrm{a}$ & $1.04 \pm 0.58 b$ & - \\
\hline 100 & $5 \times 5$ & $1.00 \pm 0.57 \mathrm{c}$ & $25.00 \pm 14.43 \mathrm{a}$ & $0.50 \pm 0.29 b$ & - \\
\hline
\end{tabular}

${ }^{\mathrm{a}}$ Means followed by the same letter are not significantly different $(p>0.05)$

Fig. 1a-d Toxicity of afidopyropen $(\mathrm{ng} / \mu \mathrm{L})$ against $D$. citri nymphs from laboratory (a) and field (b) populations, as well as adult emergence following treatment of nymphs from laboratory (c) and field (d) populations. Different letters above bars indicate that the corresponding means differ significantly according to the Bonferroni test $(p<0.001)$
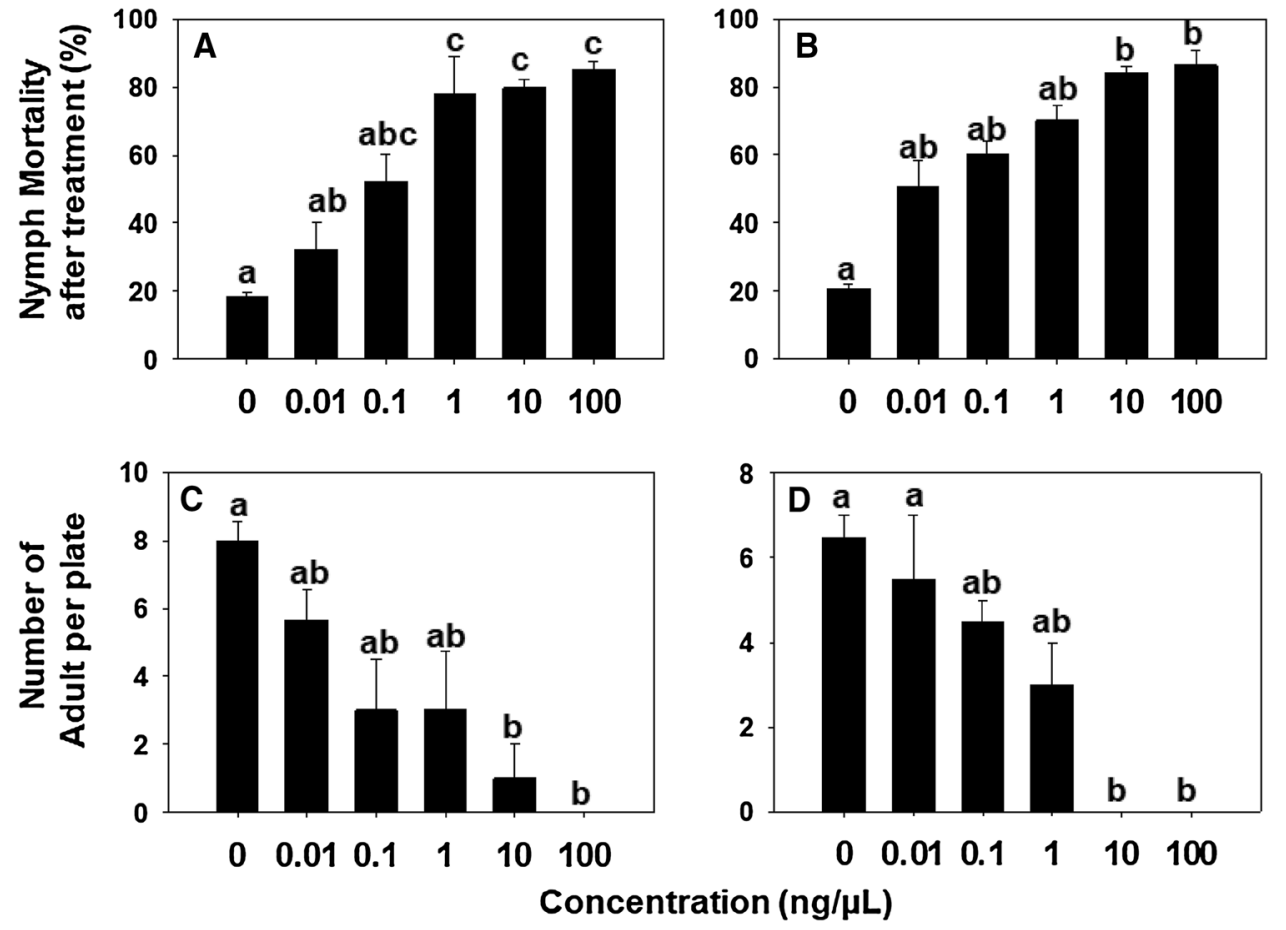


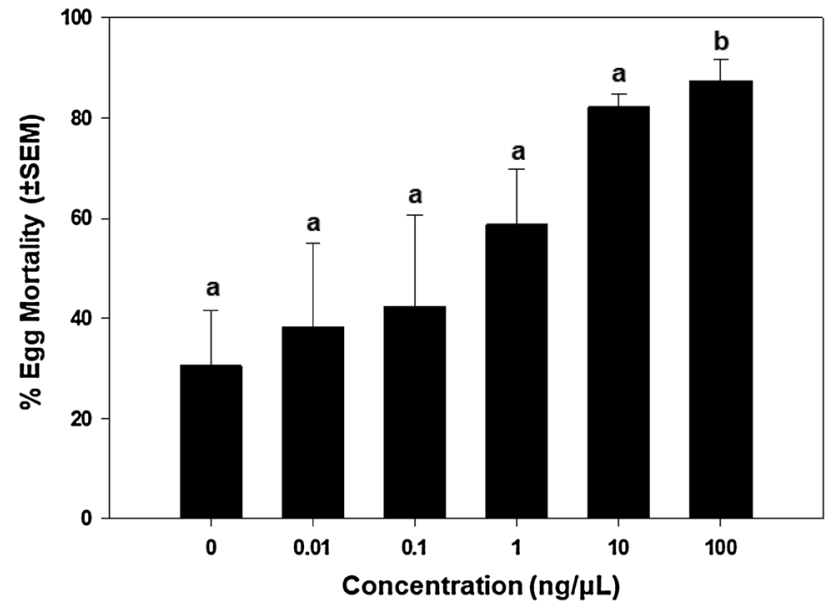

Fig. 2 Effect of afidopyropen on D. citri egg mortality following direct spray application. Different letters above bars indicate that the corresponding means differ significantly according to the Bonferroni test $(p<0.001)$

\section{Effect of afidopyropen on D. citri egg mortality following direct spray application}

Egg mortality increased with dosage (Fig. 2). Afidopyropen applied at $100 \mathrm{ng} / \mu \mathrm{L}$ significantly $(d f=5 ; F=4.25 ; p=0.01)$ reduced the hatch rate of five-day-old $D$. citri eggs (Fig. 2).

\section{Feeding behavior of $D$. citri adults}

Feeding by $D$. citri, as measured by honeydew excretion, was significantly reduced on afidopyropen-treated leaves as compared with the control after $48 \mathrm{~h}$ of feeding $(d f=5$; $F=18.61 ; p<0.001$ ) (Fig. 3). The number of honeydew droplets excreted during the $48 \mathrm{~h}$ decreased as the concentration of afidopyropen was increased; furthermore, there were significant differences in honeydew excretion between the $0.1,1,10$, and $100 \mathrm{ng} / \mu \mathrm{L}$ treatments and the control (Fig. 3).

\section{Discussion}

The purpose of this investigation was to evaluate the toxicity of afidopyropen against $D$. citri. We employed both a laboratory population that is known to be highly susceptible to all chemical classes currently registered for the management of $D$. citri in the field as well as a field population that has been exposed to regular management by conventional grower standards for at least five concurrent seasons (Chen and Stelinski 2017). Specifically, we quantified the acute toxicity and sublethal effects of afidopyropen on $D$. citri fecundity, feeding, and host settling behaviors. The results

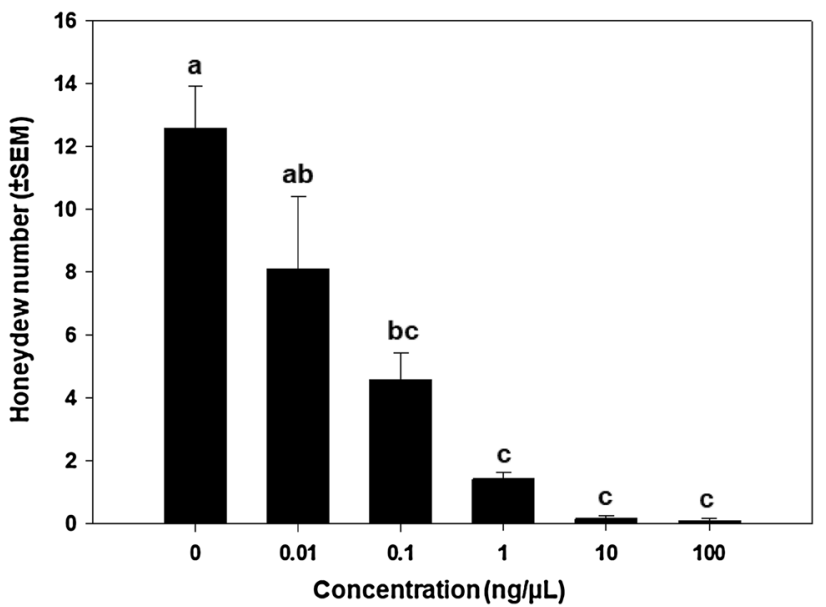

Fig. 3 Effect of afidopyropen on D. citri adult feeding as measured by the number of honeydew droplets produced. Citrus leaf discs were treated with various concentrations of afidopyropen or water. Different letters above bars indicate that the corresponding means differ significantly according to the Bonferroni test $(p<0.001)$

indicated that afidopyropen should be effective at suppressing $D$. citri populations and may have the additional beneficial effects of reducing host selection and feeding behavior.

Most toxicological research focuses on the survival/mortality of the subject. However, individuals surviving toxicant exposure may still sustain significant injury or exhibit behavioral changes in feeding, settling, and oviposition response (Stark and Banks 2003). Sublethal effects of afidopyropen on D. citri reduced oviposition and survival of nymphs as well as the number of eggs laid and subsequent adult emergence. The lowest concentration tested reduced egg, nymph, and adult emergence as compared with controls. In a similar investigation, cyantraniliprole reduced the oviposition, nymph development, and adult emergence of $D$. citri at 0.25 AI ng/ $\mu$ L (Tiwari and Stelinski 2013). D. citri maintained on plants treated with an aqueous solution of imidacloprid (0.1 $\mathrm{AI} \mathrm{ng} / \mu \mathrm{L}$ ) exhibited reduced fertility, fecundity, and nymph survival as compared with controls (Boina et al. 2009). Sublethal effects on $D$. citri have also been observed with pyriproxyfen, buprofezin, and diflubenzuron, which caused reduced development of eggs, nymphs, and adults (Boina et al. 2010; Tiwari et al. 2012). The minimum concentration of sulfoxaflor required to reduce the development of $D$. citri was found to be lower than the minimum concentrations of other insecticides required to reduce its development (Brar et al. 2017).

Some insecticides, such as cyantraniliprole (Tiwari and Stelinski 2013), imidacloprid (Boina et al. 2010), and flupyradifurone (Chen et al. 2017), reduced feeding by $D$. citri. It is important to reduce its feeding given that $D$. citri acquires and transmits the Candidatus Liberibacter sp. pathogen during feeding. Previous investigations have shown that 
continuous feeding for approximately $30 \mathrm{~min}$ on infected trees is required to successfully acquire the pathogen, and 5-7 $\mathrm{h}$ of feeding on trees is required to transmit the pathogen to healthy plants (Grafton-Cardwell et al. 2013). Therefore, the spread of HLB may be reduced by deterring the vector from feeding on citrus plants (Chiyaka et al. 2012; Nakasuji et al. 1975; Nauen 1995; Nauen et al. 1998), which serve as hosts for both the pathogen and the vector. The present study indicated that afidopyropen acts as a feeding deterrent against $D$. citri. The application of feeding deterrent substances, including insecticides, is an important component of HLB management (Grafton-Cardwell et al. 2013). The reduced fecundity of $D$. citri developing on citrus treated with lethal and sublethal concentrations of afidopyropen may be directly associated with reduced feeding. In addition to the direct effects of afidopyropen on population growth, sublethal concentrations may also reduce the rate of transmission of Candidatus Liberacter bacteria between citrus hosts as a consequence of reduced $D$. citri feeding. This hypothesis warrants further investigation; however, reduced pathogen transmission by $D$. citri caused by sublethal insecticide exposure has been demonstrated previously (Boina et al. 2011). Exposure to sublethal insecticide concentrations is known to cause physiological changes that reduce development and fecundity and lead to an overall fitness decline in certain insect species (Harnoto et al. 1984; Luckey 1968; Omer and Leigh 1995; Stark and Banks 2003). In general, exposure of hemipteran species to sublethal insecticide concentrations reduces feeding, growth, survival, and reproduction (Kerns and Stewart 2000; Lee et al. 1988; Nauen et al. 1998). Alternatively, exposure to sublethal concentrations may increase fecundity by stimulating reproduction through hormoligosis, which increases fitness (Chen and Nakasuji 2004; Chen et al. 2017). Similarly, sublethal acaricide exposures are known to stimulate the fecundity of predatory mites, Amblyseius victoriensis Womersley (Acarina: Phytoseiidae), and to increase the longevity of the twospotted spider mite, Tetranychus urticae Koch (Trombidiformes: Tetranychidae) (James 1997). Increased fecundity, larval weight, and juvenile hormone III titer were found in the rice borer Tryporyza incertulas Walker (Lepidoptera: Pyralidae) (Wang et al. 2005) following sublethal exposure to buprofezin and imidacloprid. Our results indicate that $D$. citri fits the more typical pattern observed with Hemiptera, whereby sublethal dosages of afidopyropen did not cause hormoligosis.

\section{Conclusions}

Our objective was to evaluate the response of laboratory and field populations of $D$. citri to a new insecticide, afidopyropen. We quantified both direct toxicity and sublethal effects on survival, fecundity, and behavior. Under laboratory conditions, afidopyropen was lethal to egg, nymph, and adult stages of $D$. citri. Furthermore, afidopyropen reduced nymph to adult emergence and adult host settling and feeding, and it contributed to an overall population decline in D. citri in comparison with control citrus. The direct and indirect effects of afidopyropen against $D$. citri indicate that it should be a useful tool as part of an integrated management program for D. citri and HLB management. According to Solís-Aguilar et al. (2015) and the current data, an agriculturally relevant concentration of afidopyropen should be approximately $100-150 \mathrm{mg} / \mathrm{L}$. Further field-scale testing is needed to determine how to best incorporate this new insecticide into a comprehensive rotation in citrus management. Afidopyropen may also prove valuable as a new mode of action for insecticide rotation when $D$. citri is already exhibiting significant resistance to more commonly used modes of action, such as neonicotinoids (Chen and Stelinski 2017; Kanga et al. 2016).

Acknowledgements This work was funded by the Citrus Research and Development Foundation and BASF research development. The technical assistance of Wendy L. Meyer, Angelique B. Hoyte, Kayla M. Kempton, Rosa B. Johnson, and Hunter Gossett is gratefully acknowledged.

Funding Citrus Research and Development Foundation and BASF Research and Development Fund.

\section{Compliance with ethical standards}

Conflict of interest This project was partially funded by BASF. This article does not contain any experiments with human participants or any other vertebrates.

Open Access This article is distributed under the terms of the Creative Commons Attribution 4.0 International License (http://creativeco mmons.org/licenses/by/4.0/), which permits unrestricted use, distribution, and reproduction in any medium, provided you give appropriate credit to the original author(s) and the source, provide a link to the Creative Commons license, and indicate if changes were made.

\section{References}

Baldessari M, Trona F, Angeli G, Ioriatti C (2010) Effectiveness of five insecticides for the control of adults and young stages of Cacopsylla melanoneura (Förster) (Hemiptera: Psyllidae) in a semi-field trial. Pest Manag Sci 66:308-312

Boina DR, Onagbola EO, Salyani M, Stelinski LL (2009) Antifeedant and sublethal effects of imidacloprid on Asian citrus psyllid, Diaphorina citri. Pest Manag Sci 65:870-877

Boina DR, Rogers ME, Wang N, Stelinski LL (2010) Effect of pyriproxyfen, a juvenile hormone mimic, on egg hatch, nymph development, adult emergence and reproduction of the Asian citrus psyllid, Diaphorina citri Kuwayama. Pest Manag Sci 66:349-357 
Boina DR, Youn Y, Folimonova S, Stelinski LL (2011) Effects of pymetrozine, an antifeedant of Hemiptera, on Asian citrus psyllid, Diaphorina citri, feeding behavior, survival, and transmission of Candidatus Liberibacter asiaticus. Pest Manag Sci 67:146-155

Brar GS, Martini X, Stelinski LL (2017) Lethal and sub-lethal effects of a novel sulfoximine insecticide, sulfoxaflor, against Asian citrus psyllid and its primary parasitoid under laboratory and field conditions. Int J Pest Manag 63:299-308

Chen XD, Nakasuji F (2004) Diminished egg size in fenvalerate resistant strains of the diamondback moth Plutella xylostella (Lepidoptera: Yponomeutidae). Appl Entomol Zool 39:335-341

Chen XD, Stark JD (2010) Individual and population level toxicity of the insecticide, spirotetramat and the agricultural adjuvant, Destiny, to the cladoceran, Ceriodaphnia dubia. Ecotoxicol 19:1124-1129

Chen XD, Stelinski LL (2017) Resistance management for Asian citrus psyllid, Diaphorina citri Kuwayama, in Florida. Insects 8:130

Chen XD, Culbert E, Hebert V, Stark JD (2010) Mixture effects of the nonylphenyl polyethoxylate, R-11 and the insecticide, imidacloprid on population growth rate and other parameters of the crustacean, Ceriodaphnia dubia. Ecotoxicol Environ Saf 73:132-137

Chen XD, Seo M, Stelinski LL (2017) Behavioral and hermetic effects of the butenolide insecticide, flupyradifurone, on Asian citrus psyllid, Diaphorina citri. Crop Prot 98:102-109

Chiyaka C, Singer BH, Halbert SE, Morris JG, van Bruggen AHC (2012) Modeling huanglongbing transmission within a citrus tree. Proc Natl Acad Sci USA 109:12213-12218

FFTC (2009) Management of citrus greening for the rehabilitation of the citrus Industry in Asia. http://www.fftc.agnet.org/libra ry.php?func $=$ view\%26id=20110803111826. Accessed 06 May 2018

FFTC (2012) Epidemiology and disease management of citrus HLB disease for sustainable citrus production in ASPAC. http:// www.fftc.agnet.org/library.php?func $=$ view $\% 26 i d=2013061414$ 4943\&type_id=1. Accessed 06 May 2018

Gerwick BC, Sparks TC (2014) Natural products for pest control: an analysis of their role, value and future. Pest Manag Sci 70:1169-1185

Grafton-Cardwell EE, Stelinski LL, Stansly PA (2013) Biology and management of Asian citrus psyllid, vector of the huanglongbing pathogens. Annu Rev Entomol 58:413-432

Halbert SE (2005) Pest alert: citrus greening/Huanglongbing. Florida Department of Agriculture and Consumer Services, Tallahassee

Halbert SE, Manjunath KL (2004) Asian citrus psyllids (Sternorrhyncha: Psyllidae) and greening disease of citrus: a literature review and assessment of risk in Florida. Fla Entomol 87:330-353

Hall DG, Albrigo LG (2007) Estimating the relative abundance of flush shoots in citrus with implications on monitoring insects associated with flush. HortScience 42:364-368

Harnoto R, Hamada R, Kiritani K (1984) Effect of sublethal dosages of carbaryl on the fecundity of Spodoptera litura Fabricius (Leipidoptera: Noctuidae). Appl Entomol Zool 19:404-405

Huang CH, Tsai MY, Wang CL (1984) Transmission of citrus likubin by a psyllid, Diaphorina citri. J Agric Res China 33:65-72

James DG (1997) Imidacloprid increases egg production in Amblyseius victoriensis (Acari: Phytoseiidae). Exp Appl Acarol 21:75-82

Jeschke P (2017) Latest generation of halogen-containing pesticides. Pest Manag Sci 73:1053-1066

Kandasamy R, London D, Stam L, von Deyn W, Zhao X, Salgado VL, Nesterov A (2017) Afidopyropen: NEW and potent modulator of insect transient receptor potential channels. Insect Biochem Mol Biol 84:32-39

Kanga LH, Eason J, Haseeb M, Qureshi J, Stansly PA (2016) Monitoring for insecticide resistance in Asian citrus psyllid (Hemiptera: Psyllidae) populations in Florida. J Econ Entomol 109:832-836
Kerns DL, Stewart SD (2000) Sublethal effects of insecticides on the intrinsic rate of increase of cotton aphid. Entomol Exp Appl 94:41-49

Kiritani K, Su HJ (1999) Papaya ring spot, banana bunchy top, and citrus greening in the Asia and Pacific region: occurrence and control strategy. JARQ 33:23-30

Langdon KW, Rogers ME (2017) Neonicotinoid-induced mortality of Diaphorina citri (Hemiptera: Liviidae) is affected by route of exposure. J Econ Entomol 110:2229-2234

Lee CY, Yap HH, Chong NL (1988) Sublethal effects of deltamethrin and propoxur on longevity and reproduction of German cockroaches, Blattella germanica. Entomol Exp Appl 89:137-145

Leichter CA, Thompson A, Johnson BR, Scott JG (2013) The high potency of ME-5343 to aphids is due to a unique mechanism of action. Pestic Biochem Physiol 107:169-176

Liu YH, Tsai JH (2000) Effects of temperature and life table parameters of the Asian citrus psyllid, Diaphorina citri Kuwayama (Homoptera: Psyllidae). Ann Appl Biol 137:201-206

Luckey TD (1968) Insecticide hormoligosis. J Econ Entomol 61:7-12

Nakasuji F, Kiritani K, Tomida E (1975) A computer simulation of the epidemiology of the ricedwarf virus. Res Popul Ecol 16:245-251

Narouei-Khandan HA, Halbert SE, Worner SP, van Bruggen AHC (2015) Global climate suitability of citrus huanglongbing and its vector, the Asian citrus psyllid, using two correlative species distribution modeling approaches, with emphasis on the USA. Eur J Plant Pathol 144:655-670

Nauen R (1995) Behaviour-modifying effect so flow systemic concentrations of imidacloprid on Myzus persicae with special reference to an antifeeding response. Pestic Sci 44:145-153

Nauen R, Elbert A (1997) Apparent tolerance of a field-collected strain of Myzus nicotianae to imidacloprid due to strong antifeedant responses. Pestic Sci 49:252-258

Nauen R, Hungenberg H, Tollo B, Tietjen K, Elbert A (1998) Antifeedant effect, biological efficacy and high affinity binding of imidacloprid to acetylcholine receptors in Myzus persicae and Myzus nicotianae. Pestic Sci 53:133-140

Nilius B, Owsianik G (2011) The transient receptor potential family of ion channels. Genome Biol 12:218-229

Omer AD, Leigh TF (1995) Sublethal effects of acephate and biphenate on fecundity, longevity, and egg viability in greenhouse whitefly (Hom., Aleyrodidae). J Appl Entomol 119:119-122

Prabhaker N, Toscano NC (2007) Toxicity of the insect growth regulators, buprofezin and pyriproxyfen, to the glassy-winged sharpshooter, Homalodisca coagulata Say (Homoptera: Cicadellidae). Crop Prot 26:495-502

Qureshi JA, Kostyk BC, Stansly PA (2014) Insecticidal suppression of Asian citrus psyllid Diaphorina citri (Hemiptera: Liviidae) vector of huanglongbing pathogens. PLoS One 9:e112331

Rogers ME (2008) General pest management considerations. Citrus Ind 89:12-17

SAS Institute (2002-2012) SAS users guide. SAS Institute, Cary

Shinohara K, Yuda T, Nishimoto H, Hamashima A, Hashimoto S, Tokimura K, Satou T (2006) Survey of citrus huanglongbing (greening disease) on the Amami Islands. Characteristics of distribution in the Amami Islands. Kyushu P1 Prot Res 52:6-10 (in Japanese with English abstract)

Snodgrass GL (1996) Glass-vial bioassay to estimate insecticide resistance in adult tarnished plant bugs (Heteroptera: Miridae). J Econ Entomol 89:1053-1059

Solís-Aguilar JF, Cruz MLP, Tejeda-Reyes MA, José Francisco DíazNájera JF, Marroquín-Pérez TS (2015) Afidopyropen, new insecticide for the control of the Asian citrus psyllid Diaphorina citri (Hemiptera: Liviidae). Entomol Mex 2:442-445

Stansly PA, Rogers ME (2006) Managing Asian citrus psyllid population. Citrus Ind 87:17-19 
Stark JD, Banks JE (2003) Population-level effects of pesticides and other toxicants on arthropods. Annu Rev Entomol 48:505-519

Stark JD, Tanigoshi L, Bounfour M, Antonelli A (1997) Reproductive potential: its influence on the susceptibility of a species to pesticides. Ecotoxicol Environ Saf 37:273-279

Tiwari S, Stelinski LL (2013) Effects of cyantraniliprole, a novel anthranilic diamide insecticide, against Asian citrus psyllid under laboratory and field conditions. Pest Manag Sci 69:1066-1072

Tiwari S, Pelz-Stelinski K, Stelinski LL (2011) Effect of Candidatus Liberibacter asiaticus infection on susceptibility of Asian citrus psyllid, Diaphorina citri, to selected insecticides. Pest Manag Sci 67:94-99

Tiwari S, Clayson PJ, Kuhns EH, Stelinski LL (2012) Effects of buprofezin and diflubenzuron on various developmental stages of Asian citrus psyllid, Diaphorina citri. Pest Manage Sci 68:1405-1412
Tomimura K, Inoue H, Iwanami T (2014) Development of simple sequence repeat markers for the Japanese population of the Asian citrus psyllid, Diaphorina citri (Hemiptera: Psyllidae). Appl Entomol Zool 49:353-357

Wang AH, Wu J, Yu Y, Liu J, Yue J, Wang M (2005) Selective insecticide induced stimulation on fecundity and biochemical changes in Tryporyza incertulas (Lepidoptera: Pyralidae). J Econ Entomol 98:1144-1149

Yasui M, Fukada M, Maekawa S (1985) Effect of buprofezin on different developmental stages of the greenhouse whitefly, Trialeurodes vaporariorum (Westwood) (Homoptera: Aleyrodidae). Appl Entomol Zool 20:340-347 